\title{
MAKING SENSE OF A STORY: ILLUSTRATIONS FROM A CASE STUDY OF ENTERPRISE RISK MANAGEMENT
}

\author{
Abdelmoneim Mohamed Metwally ${ }^{1}$
}

\begin{abstract}
The concern of this paper is methodological. It reports on how methodology and methods are coupled with the theory used in a case study. This is illustrated from my study on transformation of management control from a monologic form to a heterogenic one through the implementation of Enterprise Risk Management (ERM) in an Egyptian firm. Having stimulated by the critiques developed against positivistic research in management, this paper explains what philosophical rationales justified this methodological choice and how a particular theoretical framework advanced an argument about how the above transformation occurs. The paper concludes that case study research can only be acceptable if the story is suitably theorised to make contribution to knowledge.
\end{abstract}

\section{Introduction}

This paper illustrates how a researcher's philosophical stance gives shape to the methodological choice and subsequent research procedures. The illustrations are linked to one of recent studies on how Enterprise Risk Management (ERM) has made a complex transformation in the practices of management controls within an Egyptian firm. The complexities in this transformation were related to the social, political and contextual factors surrounding risk-based management controls (RBMC). The type of case study method I used enabled me to illustrate that cascading of EMR was disrupted by cultural change and the geopolitical shield which generated a theoretical discussion about this transformation.

This theoretical discussion enabled me to contribute to ongoing debates on institutional logics by providing empirical evidence for centrality and compatibility as determining either conflict or coexistence between logics (Besharov \& Smith, 2014). In doing so, it reinforces the idea of "bringing society back" through geopolitics, cultures, values, and identities (Alawattage, 2011;Luo, 2007; Thornton \& Ocasio, 2008). Moreover, the case study's analysis of micro level practices explored more "blind spots" in logics mobilization (Cloutier \& Langley, 2013) highlighting control issues with new cultural perspectives on MCS micro-politics in an LDC; these new perspectives concern the struggle for everyday life of controls, especially the clash of civilizations (Hopper et al., 2009; Wickramasinghe \& Hopper, 2005). The case study These contributions were possible through identifying the appropriate methodological strategy but this was not a straightforward process, as researchers must always deal with field contingencies through taking decisions. These decisions may vary based on the contingencies arising and may

${ }^{1}$ Department of Accounting, Faculty of Commerce, Assiut University, Egypt.

Email: abdelmoneam.metwali@commerce.au.edu.eg 
change the theoretical framework and data collection methods, or they may even alter the initial methodological strategy. As this paper clarifies, field contingencies changed both my theoretical framework and data depth and breadth.

This paper is thus divided into six main sections. Section 2 discusses this work's philosophical stance and the current study as a critical accounting study. Section 3 introduces issues regarding the case study method and defends choices regarding space, time, and number of visits. Section 4 provides a description of the steps carried out in line with the case study. Section 5 discusses the main data collection techniques in terms of methods deployed - namely interviews, observations, and documentary research. Section 6 explains the data analysis process and its validity. Section 7 summarizes and concludes the paper.

\title{
Research Philosophy and Choice of Paradigm
}

Stating a knowledge claim means the researcher started with certain assumptions about what will be studied and how as 'there is no such thing as a totally objective or value free investigation' ( Hopper \& Powell, 1985, p. 429). Previous assumptions and beliefs about the social world affect the research's direction (Hopper, Annisette, Dastoor, Uddin, \& Wickramasinghe, 1995; Hoque \& Hopper, 1994), questions, and approach. The last two likely derive from the researcher's ontological and epistemological assumptions (Alawattage, 2013; Burns, 2015; Hopper, 2014). To clarify these, the former represents beliefs about the nature of human beings and the social world they inhabit while the latter represents beliefs about the nature of knowledge and acquiring it (Burrell \& Morgan, 1979; Hopper \& Powell, 1985).

Accounting literature has various classification schemas for categorizing philosophical assumptions. Of these, the schemas developed by Burrell and Morgan (1979), Hopper and Powell (1985), Chua (1986), and Ryan, Scapens, and Theobald (2002) are similar as all were built on early writings of Burrell and Morgan (1979). For example, Chua (1986) and Ryan et al (2002) incorporated both radical humanist and structuralist paradigms from Burrell and Morgan (1979) to obtain critical accounting research. This integration was initiated by Hopper and Powell (1985) and over the years the category termed radical theories has come to be labelled critical accounting research (Ryan et al., 2002).

Figure 1 summarizes these categories. The figure's central idea is that all theories are established based on the philosophy of science and theory of science. In simple terms, the classification is based on two dimensions - the nature of social science and the nature of society (Burrell \& Morgan, 1979; Trevor Hopper \& Powell, 1985). The social science dimension consists of four components: assumptions about ontology, epistemology, human nature, and methodology. The other classifies two dissimilar approaches to the nature of society:

\begin{abstract}
"One is concerned with regulation, order and stability and sets out to explain why society tends to hold together, while the other focuses on the fundamental divisions of interest, conflicts and unequal distributions of power that provide the potential for radical change."
\end{abstract}

(Hopper \& Powell, 1985, p. 432). 
The horizontal axis represents substitute views about the nature of social science - from intense subjectivism to intense objectivism. The subjectivist position affirms that social science is nominalist, anti-positivist, voluntarist, and ideographic. Contrastingly, the objectivist position assumes social science to be realist, positivist, determinist, and nomothetic (Burrell \& Morgan, 1979; Hopper \& Powell, 1985). The vertical axis illustrates assumptions about the nature of society - from regulation to radical change. These dimensions are combined to shape four different research paradigms: functionalist, interpretive, radical humanist, and radical structuralist (Burrell \& Morgan, 1979; Hopper \& Powell, 1985). Chua (1986) and Ryan et al. (2002) claimed there are three paradigms: mainstream accounting research, interpretive research, and critical accounting research.

Figure 1: Classification Schema for Accounting Research

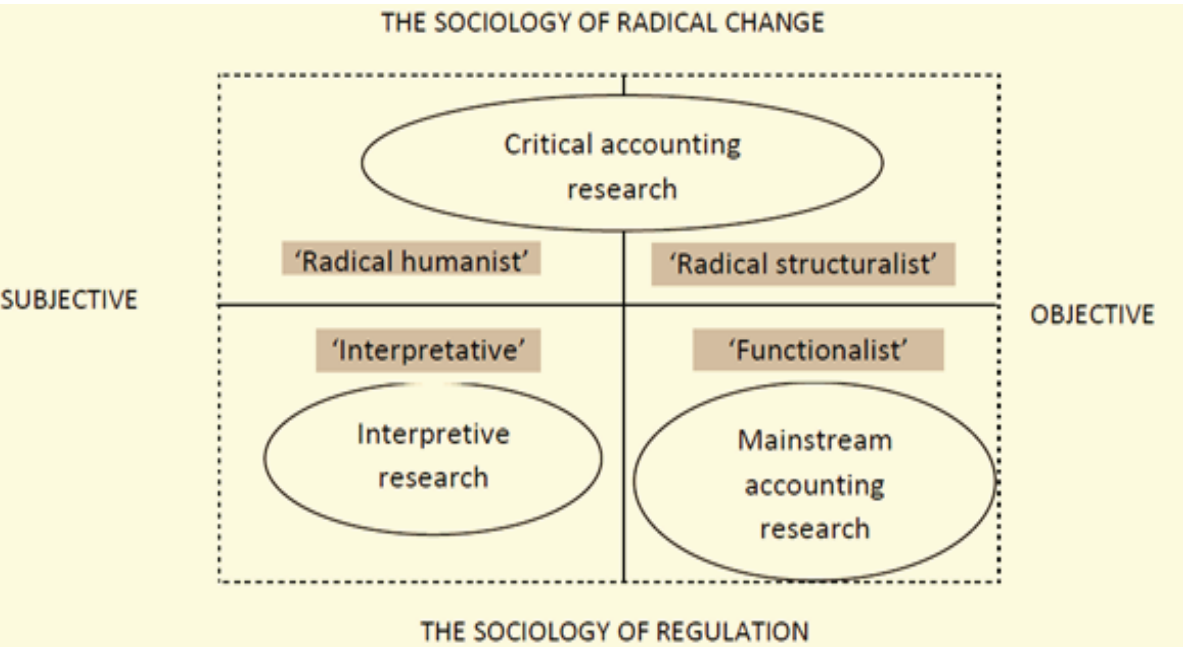

(Source: Ryan et al., 2002, p. 40)

Consequently, as the three paradigms have different assumptions and views about society and social science, they have different implications for accounting research. Table 1 summarizes these assumptions with three general categories: beliefs about knowledge, beliefs about physical things, and the relationship between theory and practice.

My study needs approaches that facilitate the focus on MAC practices in LDCs and how these are shaped by cultural and political factors, because imposing and transplanting a Western blueprint (ERM) involves socio-political interactions. These are rooted in everyday practices but to fully understand MAC practices, the researcher must not only question and examine social, economic and political contexts, but also recognize the role of power and conflict in shaping and reshaping the practices that appear before us (Cooper \& Hopper, 2006; Hopper et al. , (1986); Hopper, Storey, \& Willmott, 1987). Consequently, the current study is positioned at the intersection of the objective/subjective, the radical change/regulations continua of Burrell and Morgan (1979), the radical theories category of Hopper and Powell (1985), and the critical perspective outlined by both Chua (1986) and Ryan et al. (2002). 
Defining critical accounting is crucial though doing this in general terms is very difficult and problematic as the literature proposes many definitions and classifications (Broadbent, 2002; Cooper \& Hopper, 2006; Jones \& Dugdale, 2001; Laughlin, 1999; Neu, Cooper, \& Everett, 2001). My study follows Cooper and Hopper (2006) proposition about the four contributions to our knowledge critical MA studies added to our understanding about MAC:

"First, the idea of changing regimes identifies the chameleon-like ability of accounting to reflect (and sustain) regimes of power over time...Second, the stress on the macro emphasizes that accounting is not an inevitable outcome of market forces or technological change but is implicated in, and reflects political, social and economic struggles...Third, MA is associated with struggles for control rooted in organizational processes and their socio-economic context: the macro and micro are reciprocally related. Fourth...Issues of individual agency, subjectivity and identity bearing on conflict and consent in life are integral to any critical analysis."

(Cooper \& Hopper, 2006, p. 209)

Following this proposition, the current research proposes that social reality consists of real relations that are interacting within macro/micro social, political, and economic struggles. Such struggles (re)produced by human agents are apt to transformations through both the subjective interpretations of these human agents and the actions driven by these interpretations. Having said this, human beings are reflexive agents and their subjectivity is an important part of understanding how their identity and reflexivity react to macro pressures. These reactions may lead to resistance and/or compromise, as later chapters will explain.

Consequently, this work deploys qualitative research in a single case study. This choice enables rich in-depth information about socio-political struggles in everyday practices through this case's ERM transplantation. Using a case study is also in line with several assertions previous research made about the suitability of case studies for critical accounting research (Alawattage, 2013; Chua, 1986; Cooper \& Hopper, 2006; Hopper, 2014; Hopper \& Hoque, 2006; Hopper \& Powell, 1985; Hoque \& Hopper, 1994). Finally, as this follows critical abductive research, the researcher is considered a bridge between the case site and the research's iteration process between theory and data. The researcher has their reflexive agency while they are working.

In turn, the idea that researchers are fully independent of the social realities they investigate is rejected in favour of acknowledging both the inevitable interaction between the two and the reflexivity researchers' exercise when interpreting findings (Burns, 2015; Hopper, 2014; Wickramasinghe, 2011). 
Table 1: Assumptions about Accounting Research Paradigms

\begin{tabular}{|c|c|c|c|}
\hline & $\begin{array}{l}\text { Mainstream accounting } \\
\text { research }\end{array}$ & $\begin{array}{l}\text { Interpretive accounting } \\
\text { research }\end{array}$ & $\begin{array}{l}\text { Critical accounting } \\
\text { research }\end{array}$ \\
\hline Knowledge & $\begin{array}{l}\text { Theory and practice are } \\
\text { independent of each } \\
\text { other and quantitative } \\
\text { methods of data } \\
\text { collection are favored } \\
\text { as based for } \\
\text { generalization. }\end{array}$ & $\begin{array}{l}\text { Theory is used to } \\
\text { provide explanations of } \\
\text { human intentions. Its } \\
\text { adequacy is assessed } \\
\text { via logical consistency, } \\
\text { Subjective } \\
\text { interpretation and } \\
\text { agreement with the } \\
\text { actors. }\end{array}$ & $\begin{array}{l}\text { Criteria for judging } \\
\text { theories are always } \\
\text { temporal and context- } \\
\text { bound. Social objects } \\
\text { can be understood only } \\
\text { through a study of their } \\
\text { history and change } \\
\text { within the totality of } \\
\text { relations. }\end{array}$ \\
\hline $\begin{array}{l}\text { Physical and social } \\
\text { reality }\end{array}$ & $\begin{array}{l}\text { Empirical reality is } \\
\text { objective and external } \\
\text { to subject and } \\
\text { researcher. Human } \\
\text { actors are essentially } \\
\text { passive objects, who } \\
\text { rationally pursue their } \\
\text { assumed goals. Society } \\
\text { and organizations are } \\
\text { basically stable and } \\
\text { dysfunctional behavior } \\
\text { can be managed } \\
\text { through the design of } \\
\text { control systems. }\end{array}$ & $\begin{array}{l}\text { Reality is socially } \\
\text { created and objectified } \\
\text { through human } \\
\text { intentions. Human } \\
\text { action is intentional and } \\
\text { has meaning grounded } \\
\text { in the social and } \\
\text { historical context. } \\
\text { Social order is assumed } \\
\text { and conflict mediated } \\
\text { through shared } \\
\text { meanings. }\end{array}$ & $\begin{array}{l}\text { Empirical reality is } \\
\text { characterized by } \\
\text { objectivity but is } \\
\text { transformed and } \\
\text { reproduced through } \\
\text { subjective } \\
\text { interpretation. Human } \\
\text { intention and rationality } \\
\text { are accepted but have } \\
\text { to be analyzed } \\
\text { critically, because } \\
\text { human potential is } \\
\text { alienated through false } \\
\text { consciousness and } \\
\text { ideology. Fundamental } \\
\text { conflict is endemic in } \\
\text { society. Because of } \\
\text { injustice }\end{array}$ \\
\hline $\begin{array}{l}\text { Relationship between } \\
\text { accounting theory and } \\
\text { practice }\end{array}$ & $\begin{array}{l}\text { Accounting is } \\
\text { concerned with means, } \\
\text { not ends, it is value } \\
\text { neutral and existing } \\
\text { institutional structures } \\
\text { are taken for granted. }\end{array}$ & $\begin{array}{l}\text { Accounting theory } \\
\text { seeks to explain action } \\
\text { and to understand how } \\
\text { social order is produced } \\
\text { and reproduced. }\end{array}$ & $\begin{array}{l}\text { Theory has critical } \\
\text { imperative, in } \\
\text { particular, the } \\
\text { identification and } \\
\text { removal of domination } \\
\text { and ideological } \\
\text { practices. }\end{array}$ \\
\hline
\end{tabular}

(Adapted from: Chua 1986,605-615)

\section{Choice of the Case Study Method}

The choice of qualitative research based on a single case study was made at the beginning of my research journey in January 2013. It came from the need for deep information about everyday life, which is what qualitative case studies are about, as (Mason, 2002) clarified:

\footnotetext{
"Through qualitative research we can explore a wide array of dimensions of the social world, including the texture and weave of everyday life, the understandings, experiences and imaginings of our research participants, the ways that social processes, institutions, discourses or relationships work, and the significance of the meanings that they generate. We can do all of this qualitatively by using methodologies that celebrate richness, depth, nuance, context, multi-dimensionality and complexity rather than being embarrassed or inconvenienced by them."
} 


\title{
In Defence of the Case Study
}

A case study uses multiple sources of evidence to investigate a phenomenon within its real-life context, especially when the boundaries between phenomenon and context are not clearly evident. It is usually useful when 'how' and/or 'why' questions are being posed (Stake, 1995; Yin, 2009), when the researcher has little control over the empirical reality under investigation, and when trying to make sense of the phenomenon in its socio-political context (Scapens, 1990). For me, case studies also represent a detailed and intensive analysis of a location such as community and/or organization and how such contexts have their own political games, understanding, and beliefs that affect their sense making and practices. The analysis chapters examine and explain certain specific conditions and contextual factors regarding transplanting RBMC and how this leads to the instantiation of a geopolitical shield to defend monologic MC. In short, the case study concentrates on the complex nature and conditions surrounding certain phenomena (Stake, 1995). These are social, political, and economic in nature, and they caused the community studied here to create its geopolitical shield as a proper response to Western blueprint imposing and transplanting its technology there.

A qualitative case study is now a well-known research design and the time to defend it has gone (Ahrens et al., 2008; Cooper, 2008; Parker, 2012), though a corpus of work still discusses issues like generalization, replication, validity, and reflexivity in qualitative research (Bryman, 2012; Lukka \& Modell, 2010; Parker, 2012; Ryan et al., 2002; Scapens, 1990; Yin, 2009). These are described as limitations but may give wrong perceptions regarding conducting qualitative case studies simply because they are not universally accepted. In response, Parker (2012, p. 59) noted:

\begin{abstract}
"In terms of reflexivity and rigour, the response...is that the qualitative researcher inhabits a different domain, embracing and becoming involved in the world of the researched (rather than seeking to be removed and independent), and seeking to produce credible accounts and interpretations (rather than assuring replicability through notions of validity and reliability). The qualitative research mission and agenda is different, in that its focus and outcomes privilege critique, theory development, uniqueness and context. While not rejecting notions of replicability where they can be delivered, our greater concern is with identifying and unpacking the unique and the different. On these grounds we embrace what the quantitative tradition avoids, and explain and evaluate our research in different terms."
\end{abstract}

In line with Parker's proposition that qualitative research is different from quantitative functional research, some qualitative case study scholars tend to ignore what positive researchers call case study limitations (Dul \& Hak, 2008; Hancock \& Algozzine, 2006; Stake,1995). These scholars just concentrate on case study design and implementation, and what can be counted as good cases and how to engage with participants and data. The reason behind this ignorance is that they see that each research design has its limitation. If qualitative studies have problems with the above issues, quantitative studies have other problems. Yes, the latter are generalizable 
statistically, but they lose real-life experience and detailed information about how and why the practices are done as they appear.

Consequently, what positivist researchers call case limitations represent 'prejudice against case study' (Yin, 2009) so please allow me to reply to these critiques individually. First, regarding generalization and replication critiques, these case studies allegedly do not allow these. While I believe that such critiques are rooted in positivist ontological and epistemological stances and can be considered only in case-based research within this paradigm, asking qualitative case studies to make generalizations and replications reveals a misconception about reasons for doing qualitative studies. Case studies' main purpose is not to make practical replications and generalizations. Qualitative case studies support theoretical propositions about the context studied, which may be extended or mobilized in other contexts. This theoretical generalization is what the qualitative case studies provide through single or multiple cases (Bryman, 2012; Parker, 2012; Yin, 2009).

Secondly, the validity critique is the most important not just because it relates to positivism but because some qualitative studies very much focus on this issue, or the crisis of validity (Lukka \& Modell, 2010; Danture Wickramasinghe, 2011). Validity construction in qualitative research has different approaches. Yin (2009) proposed that validity construction comes from multiple sources of evidence in data collection, or what Hopper and Hoque (2006) called methodological triangulation, and establishing chains of evidence that stand as valid. For analysing data, internal validity remains crucial and arrives through pattern matching, explanation building, and time series analysis. Finally, reliability comes through using case study protocol and producing data bases while collecting data.

Lukka and Modell (2010) offered further strategies for enhancing the validity of interpretive MA research, using abductive research and making combinations between emic/etic. This mix between inductive/deductive and emic/etic resolves the validity crisis. (Wickramasinghe, 2011). The current research follows this stance (see Section 4.5). As researchers should take 'opportunistic' approaches in the field, analysis and validation, hence fieldwork, is permeated by conflict between what is theoretically desirable and what is practically possible. (Alawattage (2013) and Hopper (2014) call fieldwork the 'art of the possible' and suggest maximizing opportunities offered in real-life circumstances. This is largely the stance the present research takes.

Finally, regarding researcher reflexivity and independence, it is difficult for the researcher to detach from the case studied. As stated at the outset, I do not consider myself, as a researcher, to be independent, objective, and/or an unbiased observer of the empirical reality investigated. Instead, I consider myself an integral part of the data collection, analysis, and interpretation process. The reason for taking this position, because following case study protocols and the analysis coding and reflecting on a theory procedures, will not produce fully independent and unbiased analysis. 


\section{On Space and Time}

This section briefly describes decisions on space, time, number of visits, data collection plan, and variations. It concentrates only on issues relevant to this chapter's methodological discussion (Chapter 6 gives more details on the studied organization). The choice of XYZ insurance company was made very early on (March 2013); a key factor was that ERM implementation is not well developed in Egypt's financial sector. Egyptian banks and insurance companies must implement Basel II and Solvency II, especially after the $2008 / 9$ global financial crisis, to maintain their internationally recognized legitimate institution ratings.

Given the research focus of RBMC, choosing an insurance company rather than a bank was made for three main reasons. First, insurance companies are well developed in using risk technologies as it is their main tool for assessing hazards, premiums, and reserving. So, my main concern at that time was what sort of change ERM could make in the pre-existing MCS. Secondly, to analyse the conflict or co-operation between the ERM team, underwriters, and reinsurance technicians as old and new risk experts inside the company. Thirdly, to study how deep ERM practices are in company operations in terms of how ERM changed the reserving, underwriting, and premium calculations.

By April 2013, company access was gained through personal and family relations with the company's Vice Chairman and CFO. After this, I started finalizing ethical approval to start collecting data. In mid-April I contacted the Vice Chairman and $\mathrm{CFO}$, and they connected me to the CRO through Skype. After having informal Skype conversations, I received the company charts, budgets, and books by email. From these talks and documents, initial decisions regarding the case study's design were made.

First, regarding space the initial plan was to concentrate on the main office's transactions that ERM affected and not selling units (the company's 30 regional branches). The pilot study was conducted accordingly, but when I realized that ERM changes reach every aspect of company operations I changed the unit of analysis and space studied to contain two regional branches and thus also understand how micro level operational selling units are affected by and react to these changes.

Secondly, the time chosen was random. The business is an ongoing process and the past no doubt affects the present, so it was difficult to define a starting and ending time. Initially, I decided on two visits: one during the pilot study's two weeks in July 2013; the other during the main study between August and November 2014 as my sponsor (the Egyptian government) does not allow more than two visits to the field as a funding condition. Then, if necessary, I could have further Skype contact with the interviewees.

My initial thought - which subsequently happened in the field - was to choose key events in company processes such as changes in MCS, management staff, rating institutions, laws and regulations, and revolutions to see if and if so how these 
affected operations. This strategy allowed bridge-building between the past and present to give context specificity and to make myself part of company happenings. Although I was not in the company during ERM initiation, through interviews, informal conversations, and documentation I gained useful insights into processes. In addition, through observation, I witnessed the company's present situation.

\section{Research Steps}

\section{Towards a Pilot Study}

The pilot study was done in July 2013 (two weeks) after around 8 hours of Skype conversations with the company $\mathrm{CRO}, \mathrm{CFO}$, and Vice Chairman. My main assertion was the role of new RM technologies - namely ERM as a governing tool in changing pre-existing MCS. Next came one general weeklong observation and four interviews without predefined questions. This unstructured approach allowed familiarization with the context, identification of possible interviewees, amending and narrowing of focuses, broad MCS understanding, and receptiveness to any new interesting issues.

From the pilot study, I understood more about certain company operations, MCS, and risk issues. First, top management was prioritizing Solvency II implementation in their strategic plan to retrieve the rating with Standard and Poor's and/or A.M. Best. This required many structural and procedural company changes such as in reserving methods, premium calculations, underwriting procedures, IT system, and budgeting calculations and follow ups. Secondly, the MCS is not concentrated in one or two departments as the company has several controls under different managers. These managers have very high interdependency levels in their work. For example, the budgeting team prepares the budget and follows up budget targets but insurance experts prepare budget benchmarks. Insurance experts include the reinsurance team, underwriters, and actuarial experts. Each plays a part in budget target setting: underwriters set selling prices (premiums), the reinsurance team reinsures premiums and claims expectations, and the actuarial experts are responsible for expecting claims, reserving, and investment targets. Thirdly, the ERM team's inclusion in the company changed traditional budgets to risk based flexible budgets and they follow up movements in targets with tools like KPIs, which have four colours. Red for high or critical risks that need immediate intervention. Orange for medium not accepted risks that need intervention immediately after critical ones. Yellow for medium, which do not need intervention (for now). Finally, green for low risks. Identifying the risk level relates to the company appetite in every aspect of risk. Fourthly, the ERM team can access all company files and departments, and their decisions are soundly followed because they have the full support of top management. Including the ERM team required many structural changes in responsibilities of some existing department like the increased role of the internal audit department and establishing new departments like the claims review department.

From early reflections on the case site, I started identifying targets for the main interviews and was satisfied that the main office's transactions would be sufficient. 
The plan to grasp the totality of omnipresent MCS involved including main office insurance producers (Sales team), internal auditors, ERM members, accountants in the finance and investment department, the budgeting team, the reinsurance team, and some underwriters. As controls were everywhere and there was no management accounting department or cost accounting at all, and the MAC I knew academically is distributed throughout departments, I needed to trace it to find my way in the case.

After the pilot study journey I started thinking about how and why the shift to RBMC changed everything. From rereading old literature on risk and new emerging articles in the field like the special issue in Management Accounting Research Journal of July 2013 about Risk, RM, and MAC, I started formulating my ideas around Foucauldian power/knowledge. This initial idea then developed into governmentality. Building on this, the research's main questions, finalized in January 2014, were directed towards this theoretical lens and my main assertion was how risk technology produces controllable controllers. As the ERM team represents experts who are using risk technologies power and their knowledge to govern the company, while they are themselves governed by the same technology.

\section{The Main Study that Abandoned Foucault}

Before travelling to the main study, interview schedules and themes were prepared based on theory and pilot study data. These included 19 scheduled interviews with various groups, which increased through unscheduled interviews and extensions in the study's scope. The main data collection period was from 8 August to 12 November 2014. I spent 12 weeks in the company for interviewing, observing, and collecting documents. Within this period, the company Vice Chairman allowed me to attend audit committee, governance committee, and risk committee meetings to observe and take notes (no recording as these meetings discuss very sensitive information about the company's controls and risk procedures).

In these 12 weeks I visited the company daily and my working days were from 8:30 a.m. to 5 p.m., including tea and lunch breaks. The CFO kindly offered me a small meeting room with an office though it was rarely used as most time was spent moving around the company, observing, making informal conversations, and collecting documents. Even the interviews mostly took place in the interview office. Actually, this room was used only twice for interviewing and for writing up notes, leaving my laptop or collected documents until the end of the day.

The Internal Auditing general manager - a certified trainer in the Egyptian Academy of Insurance - invited me to attend four weeks workshop training for insurers on ERM and Solvency II, organized by the Egyptian Financial Supervisory Authority [EFSA] and Insurance Federation of Egypt [IFE]. This offered opportunities to understand more about ERM in the Egyptian insurance market and how most Egyptian insurance practitioners perceive and implement this Western blueprint. It was organized for weekends so no data collection time was missed by attending this workshop. It also gave me more time with some company employees outside the formal company environment and hence allowed many informal conversations. 
The first two and a half weeks of data collection confirmed my early assertions. Hence, everything was going as planned and most interviewees talked about the power of the ERM team, how they have full support from top management, and what sort of change they made in their department. All these were supported by observing the ERM team work over the first two weeks. In line with this were patterns and notions from the governmentality framework rationale. The first problem was that most regional branch managers and employees were not replying on time to the ERM team's emails (average delay time of around one week). This did not initially seem a big issue for me, as the regional branch managers and employees have workloads in branches so this was not a research priority. Moreover, branches were initially outside my study scope.

Everything changed when I started observing and interviewing the underwriters. Their work is totally independent from the ERM team, they try to downplay what the ERM team is doing, and some of them violate direct orders from the ERM team in selling prices, and reserving and accusing them as being nescient about insurance risks. At that time, I realized that my theoretical lens of Foucauldian governmentality should be rethought as it is about controlling people's lives but omits resistance to and/or conflict over the technology of governing.

Before making this difficult, unexpected choice, I asked the ERM team about what I observed in the underwriting team and why they do so. They said they are in charge and underwriters must follow them. Underwriters may have their reasons for deviating, such as being more connected to the market, and they are not disrupting the total flow of ERM operations. This response did not explain what I observed so I decided to make things before others through changing observation plans and interview sequence. For example, I was supposed to have the reserving and investment departments' control parts in the seventh week, but because of their direct connection to the insurance experts, I made them in the fourth week to stand on to what extent there is a resistance to the ERM. I hoped I would not find such resistance in reserving and investment departments.

Unfortunately, I found that all the insurance experts were experiencing problems with ERM changes and new controlling procedures. Although some places like reserving fully complied, they do not like these changes and they included political and economic factors for why ERM is not currently suitable for the company. Furthermore, what confirmed that my theoretical lens must be changed was the audit committee's meeting at the end of week four. Regional branches' directors complained about the excessive requirements the ERM team was requesting from regional branch GMs. Also, if the team insists on changes in prices, commissions, and policy coverage, the company must downsize budget targets as their regional branch managers will not meet them with these new regulations.

This new variable, along with old unexpected conditions, changed not only my theory but also my unit of analysis as I needed to dig deeper to see how micro operational levels (i.e. regional branches) were perceiving and reacting to ERM transplantation. I contacted the CFO and the Vice Chairman, requesting permission to visit one or two regional branches. The CFO called a regional branch's GM and asked if he could meet me, and this manager was coming to the main office at the end of the fifth week with his vice to discuss a branch 
issue with the company's CEO. When I met them I arranged to visit their branch to observe it for one week and another branch for another week.

My main concern at that time was not the theoretical lens or how data could be theorized but the number of interviews and getting deeper information about why company sections were against ERM. In this sense, it was no longer an ordinary case study as it needed extending (Burawoy, 1998, 2009) as an appropriate methodological reaction to field contingencies. This involved identifying what was happening from micro to macro aspects to acknowledge total relations throughout departments and regional branches. It was also extended historically to account for different transformation stages of the case before and after ERM transplantation. It was further extended regarding space as I included observations and interviews at two regional branches' micro levels to clarify connections between the Micro, Meso, and Macro. Finally, it was extended regarding time for data collection as further Skype interviews were needed to validate subsequent theory building. These additional Skype interviews took place between February and May 2015.

Supporting this decision, (Wickramasinghe, 2015) notes that an extended case helps one understand contemporary phenomena like RBMC that are not supported by a strong theoretical base in their natural setting. Hence, it allows bottom-up analysis as it offers researchers space to be reflexive while collecting, connecting, and reflecting on empirical and theoretical implications. Extending also enabled me to build on micro and meso level data to understand reactions behind the state of resistance as it "extract[s] the general from the unique, to move from the "micro" to the "macro", to connect the present to the past in anticipation of the future, all by building on pre-existing theory' (Burawoy, 2009, p. 21). Finally, the situation in the field and abandoning initial theory midway through left extension almost as a last resort to re-build a new theory later.

\section{Data Collection Methods}

Owing to this work's critical position and the extension decision, my methodology requires two main categories of empirical data to connect the micro to the macro and reflect on the social, political, and economic conditions that produced geopolitical protectionism. The first category is data that reveals changes at the wider political-economic level and at the field Macro level. The second data set reveals changes in micro (regional branches) and meso (Main office) organizational structures and practices. Being unable to interview Egyptian Governmental officials from the Ministry of Investment or Egyptian Financial Supervisory Authority (EFSA) officials means my macro data came from secondary published materials (e.g. reports, periodical magazines, local newspapers, journal articles, and websites). Meso and micro data came from actors in the studied organization (e.g. risk officers, insurance experts, internal auditors, and accountants).

The field involved a data triangulation strategy to grasp the complexity of the newly imposed RBMC procedures and how they cascade to XYZ's grassroots operations. Hence, using multiple methods is important for in-depth understanding, provides stronger substantiation of constructs, and allows valid and reliable conclusions (Bryman, 2012; Hopper \& Hoque, 2006). As Table 2 summarizes, it took 14 weeks over 2013 and 2014 to 
understand this new system and how people reacted to it. Data collection and validation were done in four phases: first, 8 hours of telephone and Skype conversations followed the initial two week pilot study; the third phase was 12 weeks from August 2014 to November 2014 as the main study; finally, the fourth phase involved 13 hours of telephone and Skype calls in February, April, and May 2015, which confirmed the previously gathered data and the new theoretical framework's (the geopolitics of institutional logics) suitability.

\section{Interviews}

Interviewing has various classifications. Bryman (2012) identified three forms: structured, semi-structured, and unstructured. Some scholars combined semi-structured and unstructured and called them qualitative interviews (Mason, 2002), or in-depth interviews (Ritchie \& Lewis, 2003). Such scholars are not convinced totally unstructured interviews exist, as the researcher should have a plan, purpose, and predefined questions - written or otherwise (Mason, 2002). The matter therefore concerns the extent of structuring, which depends on the study's research questions and purpose (Mason, 2002; Neuman, 2007; Ritchie \& Lewis, 2003).

Largely structured interviewing usually involves closed questions to capture precise data and subsequently explain behaviour within pre-established categories, which is why most quantitative studies use them - and to confirm or extend the questioner's work (Bryman, 2012; Neuman, 2007). In contrast, in-depth and/or qualitative interviewing understands complex behaviour without imposing a priori categorization that may limit the field of inquiry. Regarding this research's philosophical stance, in-depth interviewing is crucial for understanding the social factors embedded in the micro-politics of XYZ. It is also so when the researcher's ontological position renders people's knowledge, views, experience, or interactions meaningful by investigating these, and when knowledge is understood as contextual and situational matter that needs in-depth understanding of the complex context and interactions (Mason, 2002).

This work had 46 interviews ( 35 face to face; 11 by Skype and telephone), which vary in structure according to the purpose and time. For instance, the 7 pilot study interviews were conducted with 4 main interviewees - the company's Vice Chairman, CEO, CRO, and CFO. Owing to the nature of the pilot study and the undetermined theoretical framework, these interviews were mostly unstructured.

They were more like open conversations to understand XYZ's operations, MCS, and ERM inclusion steps and changes after implementation. In the main study and during my daily visits to the main office in Cairo and two regional branches (Assiut and AL-Mansoura), 31 formal interviews were conducted with different participants from various departments. I interviewed 8 accountants, 2 regional branch managers, 4 insurance producers, 3 underwriters, 2 claims review technicians, 4 ERM team members, 3 reinsurance officers, and 5 internal auditors. Their practical experiences ranged from 3 to 35 years. The nature of the main study and changes that happened made my interviews more concentrated day by day. Finally, in validating the data and theory another 8 interviews were conducted with the CFO, CRO, 2 internal auditors, 2 risk officers, a reinsurance officer, and an underwriter. These validation interviews were much more structured and centred on 
specific points to validate or clarify.

Preparing for and actually conducting the validation interviews was not easy. They required extreme cautiousness and avoidance of leading questions (e.g. 'Do you agree with this interpretation'? or 'How do you see this interpretation?') because these may influence answers (Mason, 2002; Stake, 1995; Yin, 2009). Two examples of my questioning clarify what I did in these interviews. One relates to procedural changes and the other to validating theory and producing 'we and them' worlds.

In an interview with an internal auditor he said the ERM team is 'changing and interfering in everything', so in validating I asked if he could 'give me some examples about their interferences'. The other example relates to validating my thoughts about the mobilized theory. An underwriter said 'we will not do something that harms our sales' while criticizing the new ERM underwriting procedures and price settings. In my validation I noted that 'you said to me previously, that your main goal is sales volume and this is why you have a problem with the ERM team. Could you explain in detail more about this issue?' When he was explaining what he do not like about ERM procedures, I said 'sorry to disrupt, but how does this differ from your old procedures?'

\section{Table 2 Summary of the empirical study}

\begin{tabular}{|c|c|c|c|}
\hline Phase & Time & \begin{tabular}{|l|} 
No. of \\
Interviews
\end{tabular} & Other data sources \\
\hline Pilot Study & $\begin{array}{l}2 \text { weeks in July } 2013 \text { Approximately, } 5.5 \\
\text { hours of face to face interviews } \\
\text { Approximately } 8 \text { hours of telephone and } \\
\text { skype conversations in April, May } 2013\end{array}$ & $\begin{array}{l}4 \\
3\end{array}$ & $\begin{array}{l}\text { Company annual book, laws and } \\
\text { regulations that organize its work, } \\
\text { some local newspapers. }\end{array}$ \\
\hline Main Study & $\begin{array}{l}12 \text { weeks in August, September, October, } \\
\text { November, } 2014 \text { Approximately } 33 \text { hours } \\
\text { of face to face interview } \\
\text { Approximately } 13 \text { hours of telephone and } \\
\text { skype conversations in February, April, } \\
\text { May } 2015\end{array}$ & 31 & $\begin{array}{l}\text { Observation to the ERM and control } \\
\text { operations done on a daily basis, in } \\
\text { the main office and two regional } \\
\text { branches, attended Audit committee } \\
\text { meeting, Risk committee meeting and } \\
\text { governance committee meeting } \\
\text { Memos, booklets, risk maps, Issued } \\
\text { policies, Budgets, Letters and emails } \\
\text { to and from the governmental } \\
\text { authorities and the western reinsurers } \\
\text { (related to ERM), and financial } \\
\text { statements. } \\
\text { Four weeks workshop training for } \\
\text { insurers on ERM and solvency } \square \text {, } \\
\text { organized by the EFSA and Egyptian } \\
\text { insurance federation(EIF) }\end{array}$ \\
\hline
\end{tabular}


Interviews were recorded whenever possible and all these were transcribed. They ranged from 30 minutes to three hours depending on work circumstances, the time available with each interviewee, and subject. Most interviews, however, lasted about one hour. Most interviewees agreed to the recording, but some preferred non-recorded interviews. In some cases I switched off the recorder during interviews because of some interviewees' hesitation when mentioning sensitive topics (e.g. when commenting on attitudes and behaviours of their hierarchical superiors).

During some interviews, topics outside my scope emerged. I tried to be flexible in allowing these but also attempted to relate these back to the core issues. Similarly, the regional branches' delay and poor relationship with the ERM team was raised in two informal conversations on the fourth week of my main visit. In the fifth week this became the main topic which, as previously mentioned, led to a change of my theory.

During my visits I had the tape recorder, tablet and a notebook with me at all times. After each interview I wrote some initial impressions and the actual interviews were later transcribed. My main concern in the field was not interviews per se but about how much documentary evidence I could obtain to support interviewees' stories. Consequently, when an interviewee mentioned a specific meeting in which some relevant event had taken place, I immediately asked for a copy of memos and/or notes of the meeting.

Finally, interviewees had the freedom to speak in either Arabic or English. However, Arabic is the first language of all respondents and all interviews were in Arabic. All interviews were first transcribed in Arabic then translated. Problems in achieving accurate translations are well known and were shared by this researcher. Many original subtleties of meaning in one language are lost in translation so I kept Arabic transcripts alongside the English ones while devising my themes.

\section{Observation}

Observations can take two forms: planned (formal) observations done in interviewing or attending meetings and unplanned (informal) observations where researchers observe issues or practices while moving between departments and during breaks (Saunders, Lewis, \& Thornhill, 2007). This work sought to record observations immediately but this sometimes happened at the day's end or during breaks for convenience purposes. For example, instead of writing while having a coffee or tea with a GM, I recorded observations afterwards. Finally, observations may be participant or non-participant. The latter was intended because spending much time at the case site for the former was not feasible.

Formal observations were conducted daily during interviews and/or meetings, and/or on specified times with department GMs when reflecting on the controls. Employees gave consent to observe their work at any time. I observed three 
meetings: an audit committee meeting (end of week four), a governance meeting (week five), and a risk committee meeting (week two). I also had 9 formal observations of the following: the ERM team department (two weeks), underwriting department (two days), reinsurance department (one week), Assiut regional branch (one week), AL-Mansoura regional branch (one week), internal audit department (one week), budgeting department (two weeks), claim review department (two days), insurance producers' department (four days).

Informal observations occurred throughout my time in the company but especially during lunch and coffee breaks. Any time spent inside involved data collection, including such observations, as I had permission to move freely and even access the on-site library and other information sites. These cumulative instances of informal observations contributed greatly to knowledge about the company and to understanding what was happening.

Finally, validity and reliability of observations is also important as participants may behave differently in any observer's presence as the latter may be observing the former's work (Ritchie \& Lewis, 2003;Saunders et al., 2007; Yin, 2009). Observations thus have to be evaluated with due care, because participants may act positively or even hide problems in their MCS. A means of obviating such issues was being present every day and developing trust and social relations with everyone whereby my presence seemed natural. Being with them during breaks, lunch time, and prayers, and talking with them about non-company issues helped create a good rapport and facilitated talk about company issues.

\section{Documentation}

Many qualitative researchers see documents as meaningful and appropriate research components. Of the many different types, some exist independently of research such as insurance policies, bank statements, accounts and balance sheets, company reports, and manuals. Others can be generated for or through the research process such as charts, tables, and lists (Mason, 2002). An issue (Yin, 2009) raises regarding documents is that before any attempt to analyse them, researchers must situate the collected documents within the context in which they were produced, because all documents are written for specific purposes and audiences.

Documents provided rich information for this work and an additional means of understanding numerous organizational processes, notably regarding ERM and control systems. Diverse documentation was used including memos, booklets, risk maps, issued policies, budgets, letters to Governmental authorities and Western reinsurers (related to ERM), company certificates (ISO and rating with Standard \& Poor's), and financial statements, and even local newspapers. The researcher approached the collected documents with critical questioning, especially for those provided by the EFSA, reinsurers, and rating institutions, and with care for sensitive internal documentation. 


\section{Data Analysis and Validity Question}

While collecting data I was mostly thinking about which theory (e.g. Neo-institutional Sociology, Institutional Logics, Actor Network Theory, Bourdieu's symbolic forms and symbolic power or Dillard model) may fit what I observed and heard. Initially this was difficult as issues surfaced between key agents (e.g. the ERM team and risk experts) and their qualities (e.g. managers' power and underwriters' professional identities), representing capitals in a field or simply clashes between experts. Furthermore, the company's micro level resisted protecting routines, which may fit Neo-institutionalism and/or radical theories that concentrate on human agency and resisting Macro structures. Patterns from many theories flashed before me, but having no clear theory presented a difficult puzzle, amplified with data patterns not yet connecting. With this, I wrote whatever I felt in my notebook for subsequent reflection after the extensive data analysis to decide what best suits the data.

Later, I tried to be more systematic and follow guidance from some qualitative research books like Saunders et al. (2007). So, I tried to make flow of my activities (e.g. data reduction, data display, conclusion drawing and verification). The data reduction process started early on and continued throughout the project. It involved selecting, focusing, simplifying, abstracting, and transforming the data in the field notes and interview transcripts. After transcribing the interviews or after each visit to the field for other purposes, interview transcripts or field notes were studied carefully. My own reflections and field notes were then combined on the Arabic transcript and a summary sheet summarized issues deemed useful in the script.

The coding process followed. Initial codes were broad categories developed from research questions and data from several interviews. While searching for patterns and similarities, I was sensitive to inconsistencies such as divergent views offered by different groups. Data was organized and displayed in charts, graphs, and metrics to aid further analyses. Data coding and categorizing was conducted manually, albeit using Microsoft Word and Excel. Qualitative analysis software packages such as NVivo were not used. This decision was first because all interviews were in Arabic and all needed translating to make use of NVivo. Also, I tried to avoid programs and their limitations, as (Scapens, 2004, p. 270) advises:
"I have not found any of them helpful for my research. But I understand that others do find them very helpful. They seem most appropriate when similar questions and issues are covered in number of different interviews-for example, when structured interviews are used. But in my case research I normally use unstructured interviews and work with the word-processed transcripts."

For the translation into English the available analysis programmes were considered but these risked losing meanings and subtleties from the interviewees. The translations were thus done manually with help from professional translators 
in the UK and Egypt to retain accurate wordings and meanings.

Regarding the theory-building process, continual iterations between field observations notes, main codes identified from the data, and several theoretical frameworks occurred. This was not my choice. As noted earlier the analysis process started without any specific predetermined theory; rather, the empirically-based patterns and themes that emerged from the fieldwork were compared with various theoretical possibilities and initial theories were revised, reformulated, discarded, and supplemented accordingly.

Choosing institutional logics to meet geopolitics as my main theoretical framework was neither easy nor immediate. It took six months to clarify the theoretical model after various stages. First, I thought about how to make a different Foucauldian study by concentrating on Foucault's last lectures where he showed concerns with people's subjectivity and how ethical-based identities can fight rule-based regulations. I started the iteration process with this in mind but found no adequate match with my codes. Secondly, I made the data speak to tell a story without theory; after seeing the full storyline, I analysed what theory suitably matched the story. Thirdly, the story initially concerned how management was divided over ERM implementation. Following Major and Hopper (2005) theory about how this can produce resistance, I dug deeper. Unlike Major and Hopper (2005) I found no labour process theory as a proper frame, because I found clues about why these two blocs (ERM team and Insurance experts) are fighting. It was because of geopolitical and socio-political reasons, as geopolitics gave a new meaning to ERM as a capitalist neo-liberal new exploitation tool for securing the company for the Western investor. This meaning was only in the opposing bloc (Insurance experts), while the ERM team and their alliances in the company saw ERM is a good project for the company.

Geopolitics as the first part of my framework was challenging as most geopolitical studies are made at the macro level, mainly in international relations and political science studies. So, the final theorizing phase concerned questioned how to cascade geopolitical concepts like the clash of civilizations to the micro and meso level of analysis. After rereading institutional theory and institutional work writings, I found that institutional logics can bring these concepts to organizations' grassroots through the centrality and compatibility. From this point I focused on the geopolitics of institutional logics and how to use my data to clarify my model.

Finally, through explaining my data collection, coding, and theory building, I implicitly clarified the validity and reliability of my processes, storyline, and the built theoretical model. This contrasts with positivist, quantitative, case-based research in accounting, which is usually evaluated in terms of construct validity, internal validity, external validity, and reliability (Yin, 2009). Qualitative case-based research in (management) accounting is better judged based on criteria that better match these studies' ontological and epistemological standpoints (Ryan 
et al., 2002; Scapens, 2004). Such criteria should cover the research's procedural reliability and its external and contextual validities.

Procedural reliability - the researcher's ability to develop and implement good research design that clearly addresses research questions - was constructed through the procedures and steps explained throughout this chapter. External validity refers to the generalizability of the research's theoretical ideas and the research findings' transferability within and across contexts. This proposed theoretical model can be generalized to most Middle Eastern and North Africa regions (MENA) as it reflects a geopolitical status the region has felt since the early 2000s. Nye's $(2004,2011)$ writings about the West's incorrect use of hard power in the MENA for the last 15 years, which produced doubts about Western intentions of the region, support this claim.

Finally, contextual validity refers to the credibility of the case study's evidence and conclusions (Ryan et al., 2002, pp. 155-156). This covers the validity of empirical evidence collected, sources of evidence, and the researcher's interpretations of the evidence. The current research largely fulfils contextual validity through the extended nature of the study. Hence, the empirical evidence used for theoretical development and testing was only incorporated in the analysis after being validated across interviewees, by re-interviewing key actors. In addition, whenever characteristic distortions signalling potential unreliability in a given source emerged, the validity of the evidence obtained from that particular source was assessed before deciding whether to acknowledge or disregard it. Finally, the validity of my own interpretations of the evidence collected was assessed through the abductive reasoning approach followed in this research.

\section{Conclusion}

In a study of this kind, there were key steps and concerns. It began by positioning its philosophical stance as a critical accounting study. From this, I justified my choice of qualitative research using a single in-depth case study. I also clarified certain decisions regarding the space, time and number of visits for the field work. Section 4 described in more detail the data collection steps and how field contingencies caused changes to my theory and data depth and breadth. Section 5 gave detailed explanations of the data collection methods - interviews, observations, and documentary sources. Finally, Section 6 addressed two main issues: how the analysis produced the geopolitics of institutional logics and how the theorization and the storyline presented in the coming chapters are valid and reliable. What this concludes is that doing a case study is not just telling a story. It involves theorising through which we can make sense of the story to make a theoretical contribution to knowledge. 


\section{References}

Ahrens, T., Becker, A., Burns, J., Chapman, C. S., Granlund, M., Habersam, M., and Mennicken, A. (2008) The future of interpretive accounting research-a polyphonic debate. Critical Perspectives on Accounting, 19(6), 840-866.

Alawattage, C. (2013) Paradigms and frameworks - A PhD workshop on philosophies of accounting and management research. University of Glasgow Business School, 3-4 December.

Alawattage, C., \& Wickramasinghe, D. (2008) Appearance of accounting in a political hegemony. Critical Perspectives on Accounting, 19(3), 293-339.

Broadbent, J. (2002) Critical accounting research: a view from England. Critical Perspectives on Accounting, 13(4), 433-449.

Bryman, A. (2012) Social research methods: Oxford university press.

Burawoy, M. (1998) The extended case method. Sociological Theory, 16(1), 4-33.

Burawoy, M. (2009) The extended case method: Four countries, four decades, four great transformations, and one theoretical tradition: Univ of California Press.

Burns, J. (2015) Doing a PhD in Accounting: emphasis on qualitative research, and experience-based. University of Glasgow Business School, 21-22 July.

Burrell, G., and Morgan, G. (1979). Sociological Paradigms and Organisational Analysis. Elements of the Sociology of Corporate Life.: London: Heinemann.

Chua, W. F. (1986). Radical developments in accounting thought. Accounting Review, 61(4), 601-632.

Cooper, D., and Hopper, T. (2006). Critical Theorising in Management Accounting Research. In A. G. H. Christopher S. Chapman \& D. S. Michael (eds.), Handbooks of Management Accounting Research (Vol. Volume 1, pp. 207-245): Elsevier.

Cooper, D. J. (2008). Is there a future for interpretive accounting research? Critical Perspectives on Accounting, 19(6), 837-839.

Dul, J., \& Hak, T. (2008). Case Study Methodology in Business Research: Butterworth-Heinemann/Elsevier.

Hancock, D. R., \& Algozzine, R. (2006). Doing Case Study Research: A Practical Guide for Beginning Researchers: Teachers College Press.

Hopper, T. (2014). Workshop on Doing Qualitative Research in Accounting. University of Glasgow Business School, 1-2 May. 
Hopper, T., Annisette, M., Dastoor, N., Uddin, S., and Wickramasinghe, D. (1995). Some challenges and alternatives to positive accounting research. In S. In: Jones, Romano, C. and Ratnatunga, J. (eds.), Accounting Theory: A Contemporary Review. . Australia: Harcourt Brace.

Hopper, T., Cooper, D., Lowe, T., Capps, T., and Mouritsen, J. (1986). Management Control and Worker Resistance in the National Coal Board. In H.Willmott and D. Knights (eds.), Managing theLabour Process (pp. 109-141): Aldershot: Gower.

Hopper, T M., and Hoque, Z., (2006) Triangulation Approaches to Accounting Research. In: Hoque, Z. (edi) Methodological Issues in Accounting Research: Theories, Methods and Issues. London: Spiramus; pp. 477-486.

Hopper, T., and Powell, A. (1985) Making sense of research into the organizational and social aspects of management accounting: A review of its underlying assumptions [1]. Journal of management Studies, 22(5), 429-465.

Hopper, T., Storey, J., and Willmott, H. (1987) Accounting for Accounting - Towards the Development of a Dialectical View. Accounting Organizations and Society, 12(5), 437-456.

Hoque, Z., and Hopper, T. (1994) Rationality, accounting and politics: a case study of management control in a Bangladeshi jute mill. Management Accounting Research, 5(1), 5-30.

Jones, T. C., and Dugdale, D. (2001) The concept of an accounting regime. Critical Perspectives on Accounting, 12(1), 35-63.

Laughlin, R. (1999) Critical accounting: nature, progress and prognosis. Accounting, Auditing \& Accountability Journal, 12(1), 73-78.

Lukka, K., and Modell, S. (2010) Validation in interpretive management accounting research. Accounting, Organizations and Society, 35(4), 462-477.

Major, M., and Hopper, T. (2005) Managers divided: Implementing ABC in a Portuguese telecommunications company. Management Accounting Research, 16(2), 205-229.

Mason, J. (2002). Qualitative researching: Sage.

Neu, D., Cooper, D. J., and Everett, J. (2001) Critical accounting interventions. Critical Perspectives on Accounting, 12(6), 735-762.

Neuman, W. L. (2007) Basics of Social Research: Qualitative and Quantitative Approaches: Pearson/Allyn and Bacon.

Nye, J. S. (2004). Soft power: The means to success in world politics: PublicAffairs. 
Nye, J. S., (2011) The Future of Power, New York: Public Affairs,

Parker, L. D. (2012). Qualitative management accounting research: Assessing deliverables and relevance. Critical Perspectives on Accounting, 23(1), 54-70.

Ritchie, J., and Lewis, J. (2003). Qualitative Research Practice: A Guide for Social Science Students and Researchers: SAGE Publications.

Ryan, B., Scapens, R. W., and Theobald, M. (2002) Research method and methodology in finance and accounting.

Saunders, M., Lewis, P., and Thornhill, A. (2007) Research Methods for Business Students: Financial Times/Prentice Hall.

Scapens, R. (2004). Doing case study research. In C. Humphrey \& B. Lee (Eds.), The real life guide to accounting research (pp. 257-279): Elsevier

Scapens, R. W. (1990). Researching management accounting practice: the role of case study methods. The British Accounting Review, 22(3), 259-281.

Stake, R. E. (1995). The art of case study research: Sage Publications.

Wickramasinghe, D. (2011). Ontological dependency on epistemology strategy: interpretive management accounting research revisited Review of Management Accounting Research (pp. 543-566): Springer.

Wickramasinghe, D. (2015). Getting management accounting off the ground: post-colonial neoliberalism in healthcare budgets. Accounting and Business Research, 45(3), 323-355.

Yin, R. K. (2009). Case Study Research: Design and Methods: SAGE Publications. 